\title{
THE THREE-JUDGE COURT REASSESSED: CHANGING ROLES IN FEDERAL-STATE RELATIONSHIPS
}

IN 1910 Congress enacted a statute ${ }^{1}$ giving three-judge district courts exclusive original jurisdiction over cases in which a petitioner in a federal court sought an interlocutory injunction against the enforcement of an allegedly unconstitutional state statute. Appeals were to be taken directly to the St1preme Court. ${ }^{2}$ This legislation was a political response to a number of cases " in which federal district judges had peremptorily issued orders striking state enactments. Motivated less by hostility to the granting of injunctive relief than by concern over the precipitate manner in which a federal judge sitting alone could frustrate carefully planned state policies, Congress seemed desirous of impressing federal judges with the serious and drastic nature of the injunctive remedy. ${ }^{4}$ The three-judge device, moreover, sought greater respect and more willing compliance by those state legislators, officials, and citizenry who might naturally resent the granting of an injunction. Since 1910 the statute has been broadened by Congress to include cases in which orders of state administrative agencies are attacked as unconstitutional, ${ }^{\circ}$ and cases in which no interlocutory injunction is sought ; ${ }^{7}$ the appellate structure has remained unchanged. In its present form, as Section 2281 of the Judicial Code, it reads:

An interlocutory or permanent injunction restraining the enforcement, operation or execution of any State statute by restraining the action of

1. 36 Stat. 557 (1910), incorporated in the Judicial Code of 1911, 36 Stat. 1162-63.

2. Ibid.

3. E.g., Ex parte Young, 209 U.S. 123 (1908) ; Raymond v. Chicago Union Traction Co., 207 U.S. 20 (1907) ; Southern Ry. v. McNeill, 155 Fed. 756 (C.C.E.D.N.C. 1907).

4. Senator Bacon, one of the sponsors of the act, observed in 1908:

If these [federal] courts are to exercise the power of stopping the operation of the laws of a State and of punishing the officers of a State, then at least let it be done on notice and not hastily, and let there be the judgment of three judges to decide such questions, and not permit such dangerous power to one man.

42 Cong. Rec. 4853.

And in 1913 Senator Overman remarked:

This legislation is demanded because a few judges have sometimes hastily or improvidently issued interlocutory injunctions suspending the enforcement of a state statute....

H.R. REP. No. 1584, 62d Cong., 3rd Sess., at I.

5. See Phillips v. United States, 312 U.S. 246, 250 (1941). Senator Overman argued: [I] $\mathrm{f}$ this substitute is adopted and three judges have to pass upon the question of the constitutionality of a State statute and three great judges say that the statute is unconstitutional, the officers of the State will be less inclined to resist the orders and decrees of our Federal courts.

42 Cong. Rec. 4847 (1908).

6. 37 Stat. 1013 (1913).

7. 43 Stat. 938 (1925). 
any officer of such State in the enforcement or execution of such statute or of an order made by an administrative board or commission acting under State statutes, shall not be granted by any district court or judge thereof upon the ground of the unconstitutionality of such statute unless the application therefor is heard and determined by a district court of three judges. ${ }^{8}$

Originally, there appears also to have been a tendency by the courts to interpret its grant broadly. In 1911 the Supreme Court decided that the threejudge statute deprived the single district judge of power not only to grant, but also to deny, interlocutory injunctive relief. ${ }^{\circ}$ Moreover, in 1923 , the Court, faced with an unclear amendment to the statute embracing state administrative orders, rejected a narrow construction which would have compelled three judges to hear an attack on the constitutionality of a state administrative order only when the constitutionality of the underlying statute was questioned. ${ }^{10}$

In recent years, however, the statute has been subjected to a consistent narrowing process. The Supreme Court has significantly pared the jurisdictional grant by holding that merely pleading a statute's unconstitutionality will not suffice: the petitioner's claim must involve substantial elements of controversy. ${ }^{11} \mathrm{~A}$ district court judge may decide sitting alone where the disposition of the issue is controlled by unmistakably compelling precedent. ${ }^{12}$ Furthermore, formal impediments have been placed in the way of three-judge invocation. The petition for relief must explicitly allege a constitutional issue; in the absence of such charge, the district judge before whom the petition is initially

8. 28 U.S.C. $\S 2281$ (1958). Direct appeals to the Supreme Court from decisions of courts convened under $\S 2281$ are permitted by 28 U.S.C. $\S 1253$ (1958). The single district judge before whom the case is originally brought must determine whether it falls within the three-judge requirement. If he decides in the affirmative, he must, under 28 U.S.C. § 2284, immediately notify the chief judge of the circuit, who then designates two oller judges, at least one of whom shall be a circuit judge.

9. Ex parte Metropolitan Water Co., 220 U.S. 539 (1911).

10. Oklahoma Natural Gas Co. v. Russell, 261 U.S. 290 (1923).

11. The lack of a substantial constitutional question may appear either because the statute is clearly constitutional on its face, Dove v. Parham, 176 F. Supp. 242 (E.D. Ark: 1959); see also Ex parte Poresky, 290 U.S. 30, 32 (1933); California Water Service Co. v. City of Redding, 304 U.S. 252 (1938); Osage Tribe v. Ickes, 45 F. Supp. 179, 183 (D.D.C. 1942), or because prior decisions of the Supreme Court have settled its constitutionality one way or the other. Bailey v. Patterson, 369 U.S. 31 (1962); Water Service Co. v. Redding, supra; Booker v. Tennessee Bd. of Educ., 240 F.2d 689 (6th Cir. 1957), cert. denied, 353 U.S. 965 (1957) ; New Jersey Chiropractic Ass'n v. State Bd. of Medical Examiners, 79 F. Supp. 327 (D.N.J. 1948).

12. Where insubstantiality arises because prior cases have been decided in the plaintifi's favor, the federal court retains jurisdiction, and the district judge may grant injunctive relief. Bailey v. Patterson, 369 U.S. 31 (1962) ; Two Guys From Harrison-Allentown, Ine. v. McGinley, 266 F.2d 427 (3rd Cir. 1959). But where the insubstantiality results from overriding precedent in the defendant's favor, and there are no other ground of federal jurisdiction besides the constitutional arguments deemed to be "insubstantial," the district court must dismiss for lack of federal jurisdiction. Ex parte Poresky, 290 U.S. 30, 32 (1933); Bradley v. Waterfront Comm'n of N.Y. Harbor, 130 F. Supp. 303 (S.D.N.Y. 1955). 
presented may have no discretion to convene a three-judge tribunal. ${ }^{13}$ Moreover, a three-judge court cannot be convened where preliminary questions of statutory construction seem so substantial as to raise doubts that the constitutional question, though properly pleaded, will actually have to be resolved.14 And where the action sought to be enjoined is not directly atthorized by the legislature or by an administrative agency properly acting under state law, a single judge court is sufficient. ${ }^{\mathbf{1 5}}$

This process has taken place in the context of a concern for the possible drain on judicial manpower which extensive utilization of three-judge adjudication might create. ${ }^{16}$ And although the existing restrictions have resulted in substantial curtailment of the jurisdictional grant, the curtailment has been insufficient to satisfy the critics. One commentator has suggested the complete abolition of the three-judge system in constitutional litigation, arglling that what he deems to be the irrelevance of its special abilities to modern judicial problems renders its costs in judicial efficiency unjustified.17 Both Justice Frankfurter ${ }^{18}$ and Justice Warren ${ }^{10}$ have joined the fray against the three-judge court, though the remedies they suggest are not so radical. And, giving a note of urgency to these criticisms, the number of cases decided by three-judge courts has shown a marked increase ${ }^{20}$-an increase which appears all the more ominous in view of the overall crowding of federal court dockets.

It seems clear that both the courts and the critics, in weighing the problem of inefficiency, have been balancing the possible drain on judicial manpower

13. Case v. Bowles, 327 U.S. 92,97 (1946).

14. Kesler v. Department of Pub. Safety, 369 U.S. 153 (1962).

15. In Phillips v. United States, 312 U.S. 246 (1941), the Governor of Oklahomm invoked state constitutional powers in declaring martial law for the purpose of obstructing work on a dam project to which the United States Government was contributing financial support. The United States sought a federal injunction against further interference by tho Governor. The convening of a three-judge court to hear the suit was held to be error, on the ground that "an attack on lawless exercise of authority in a particular case is not an atatack upon the constitutionality of a statute conferring the authority even though a misreading of the statute is invoked as justification"; id. at 252; see Ex partc Bransford, 310 U.S. 354 (1940).

16. See, e.g., Kesler v. Department of Pub. Safety, 369 U.S. 153, 156, 177 n.7 (1962); Florida Lime \& Avocado Growers Inc. v. Jacobsen, 362 U.S. 73, 90-96 (1960) (Frankfurter, J., dissenting) ; Phillips v. United States, 312 U.S. 246, 250 (1941); California Water Service Co. v. City of Redding, 304 U.S. 252, 255 (1938) ; Oklahoma Gas \& Elec. Co. v. Oklahoma Packing Co., 292 U.S. 386, 391 (1934) ; Ex parte Collins, 277 U.S. 565, 569 (1928).

17. Comment, The Three-Judge Federal Court in Constitutional Litigation: A Procedural Anachronism, 27 U. ChI. L. Rev. 555 (1960).

18. Florida Lime \& Avocado Growers, Inc. v. Jacobsen, note 16 supra. In Kcsler v. Department of Pub. Safety, note 16 supra, Justice Frankfurter wrote the majority opinion establishing a "contingency" test (see text accompanying note 14 supra) which will probably have a restrictive effect, notwithstanding the upholding of three-judge jurisdiction in Kcslcr.

19. Dissenting in Kesler, the Chief Justice advocated the exclusion of all supremacy clause cases from three-judge jurisdiction where there is no other ground of constitutional attack, and noted that the special panel constituted a serious drain upon the federal judicial system. 369 U.S. at 175-77.

20. See text accompanying note 75 infra. 
against the supposed utility of three-judge courts on the basis of an assumption that the purposes of such tribunals are the same now as they were at the time of passage, half a century ago.21 But it may appear today that there has been a shift from the original grounds for passage of the special jurisdictional grant, a shift which should be accounted for in any reevaluation of three-judge courts.

To a significant extent, the sponsors of the act sought its enactment because of a growing hostility toward increasingly frequent judicial interference, through injunctive remedies, into legislative attempts to cope with economic and social evils. In an era of reform legislation, the federal courts were cast in the role of obstructionists. ${ }^{22}$ Because of this conflict, there was general agreement among both progressive and populist elements that the courts' ability to thwart the popular will through "government by injunction" must be curbed." The Progressive Party in 1912 published a declaration of principles which included, among demands for "the rule of the people," "equal suffrage," "minimum wage standards," and the "prohibition of child labor," a demand for "such restriction of the power of the courts as shall leave to the people the ultimate authority to determine fundamental questions of social welfare and public policy."24 Considering the responsiveness both major parties manifested toward public sympathy for the Progressives in the 1908 election campaign, $2=$ it appears probable that one element of the original motivation for the threejudge court act as passed was a determination to immunize progressive legislation from the harshly executed "judicial veto" power residing in the preliminary injunction.

A protective attitude toward reform legislation was not, however, the sole ground for substitution of the three-judge mechanism. Concepts of federalism at the time embodied somewhat rigid and simplistic notions of separate spheres of authority reserved to state and national governments. ${ }^{20}$ The increasingly

21. Florida Lime \& Avocado Growers, Inc. v. Jacobsen, 362 U.S. 73 (1960) ; Hutcheson, A Case for Three Judges, 47 HaRv. L. Rev. 715 (1934); Comment, The Three-Judge Federal Court in Constitutional Litigation: A Procedural Anachronism, supra note 17.

22. See Nash, Third Parties in Axrerican Politrcs 230-33 (1959); Jackson, The Struggle for Judictal Supreasacy 50-68 (1941) ; Croly, Progressive Dexrocracy 248-56 (1914) ; The Great Leaders and Natronal Issues of 1912 14-15, 56 (1912); Goodiow, Soctal Reforar and the Constitution 338-44, 357-58 (1911).

23. See Porter, National Party Platrorars 294, 296 (1924) (People's Platform of 1908); Croly, Progressive Democracy 251 (1914) (quoting Roscoe Pound); see also Payne, The Birth of THe New Party 241-45 (1912).

24. PAYNE, op. cit. stpra note 23, at 306.

25. The Republican' Taft campaigned under the banner of Roosevelt progressivism against the Democrats' Bryan. Schlesinger, Political and Soctal History of the Untred States vol. 2, 457-58 (1932). See speech of Rep. Henry, 42 Cong. Rec. (Appendix) 248 (1908); speech of Rep. Hitchcock, id. at 192.

26. See, e.g., the groping comments of Sen. Burkett:

In my opinion we have had illustrations enough of this thing in the past to show that there will come a time when Congress must, if it can, define the line of demarcation between Federal authority and State authority in this particular line of cases. 
perfunctory use of injunctive remedies by federal courts on constitutional grounds was perceived as presenting disturbing implications for the balance between state and federal authority. ${ }^{27}$ Post-Civil War implementation of civil rights and reconstruction legislation, the expansion of federal court jurisdiction, ${ }^{28}$ and the enactment of laws regulating nationwide industries ${ }^{20}$ and transportation systems ${ }^{30}$ had fostered state wariness of federal expansion. ${ }^{\text {s1 }}$ And the Supreme Court decision in Ex Parte Young, ${ }^{32}$ approving the use by lower federal courts of ex parte injunctive power against state statutes, seemed to indicate that the courts would play an aggressively creative role in the further growth of the federal power. ${ }^{33}$ In response, the three-judge court was

I have never been one of those who have had any great fear of the conflict of Federal authority and State authority. In my opinion there is no conflict and what secms a conflict is only the inability to see just where the one ends and the other begins. I believe there is a strong line of demarcation. It does not make so much difference, in my opinion, to the State or Federal authority where that line of demarcation is, but it is very important and very essential, in my mind, that we should know where that line of demarcation is.

42 Cong. Rec. 4848 (1908) ; speech of Rep. Williams, 42 Cong. Rec. (Appendix) 280 (1908). The language is reminiscent of the Supreme Court's opinion in Tarble's Case, 80 U.S. (13 Wall.) 397, 406-07 (1872) :

There are within the territorial limits of each State two governments, restricted in their spheres of action, but independent of each other, and supreme within their respective spheres. Each has its separate departments; each has its distinct laws, and each has its own tribunals for their enforcement. Neither government can intrude within the jurisdiction, or authorize any interference therein by its judicial officers with the actions of the other. The two governments in each State stand in their respective spheres of action in the same independent relation to each other, except in one particular, that they would if their authority embraced district territories. That particular consists in the supremacy of the authority of the United States when any conflict arises between the two governments....

Such being the distinct and independent character of the two governments, within their respective spheres of action, it follows that neither can intrude with its jutlicial process into the domain of the other....

See also Texas v. White, 74 U.S. (7 Wall.) 700, 721, 725 (1868); Collector v. Day, 78 U.S. (11 Wall.) 113, 124-25 (1871); The Federatist, No. 39 (Madison); Anderson, INTERGOVERNMENTAL RELATIONS IN REviEW (Intergovernmental Relations in the United States Monograph No. 10, 1960), pp. 19, 25. 250.

27. See Sen. Burkett's remarks supra note 26; speech of Rep. Henry, supra note 25, at

28. Act of March 3, 1875, ch. 137, \& 2, 18 Stat. 470.

29. E.g., Sherman Antitrust Act, § 1, 26 Stat. 209 (1890).

30. E.g., Act of Feb. 4, 1887, ch. 104, pt. I, § 11, 24 Stat. 383, establishing the Interstate Commerce Commission.

31. Cf. Hutcheson, A Case for Three Judges, sipra note 21, at 808-10.

32. 209 U.S. 123 (1908).

33. See Justice Harlan's Dissent, id. at 204 :

... such a result would, for most purposes, practically obliterate the Eleventh Amend ment and place the States, in vital particulars, as absolutely under the control of the subordinate Federal courts....

The dissent was highly praised and inserted into the Congressional Record by Sen. Bacon, one of the sponsors of the three-judge act. 42 CoNG. REC. 4853 (1908). 
conceived as a method of retarding overactive participation of the federal judiciary.

It would appear today that both of these policies are inapposite. The federal judiciary has been educated by thirty years of careful appointment by executives, and a similar period of decision-making by the Supreme Court, in the necessity of respecting the regulatory choices of state legislatures ${ }^{34}$ From a modern perspective, which recognizes elements of public interest in all significant social acts, federal courts have seen the emptiness of the due process considerations upon which they based their former obstruction of state regulatory measures. ${ }^{35}$ Moreover, even if the desires of the progressive supporters of the statute are still relevant, the reason for its continued operation would seem dubious, since the forum for progressive legislation has shifted from the state to the federal legislature. ${ }^{36}$ Finally, the basic conflict in federalism at which the three-judge device was directed seems also to have changed. Decades of enlargement of federal powers, coinciding with a marked expansion of the role played by the states in governing the lives of their citizens, have cast in an anachronistic light the doctrine that a clearly-defined, static line between state and federal powers is necessary to preserve the effectiveness of the states as relatively autonomous governing units, ${ }^{37}$ and have, as well, rendered impossible the demarcation of such a line.

In view of these political developments, it might seem that sufficient reasons for preservation of the three-judge court no longer remain to counterbalance its costs, and that it should therefore be discarded as a relic of an earlier age. The device, however, still serves one of its original functions as a valuable palliative to states which must occasionally accept the invalidation of their legislation by federal authority. ${ }^{38}$ And, more important, the same changing circumstances which worked to diminish the relevance of the original congressional intent provide important new functions which the three-judge court may-be able to perform. Since state and federal governmental responsibilities have shown a marked tendency to overlap, ${ }^{30}$ a situation where conflict between national and local regulation is unavoidable in the absence of cooperation has been created. Consequently, the need for recognition of the superior claims of the former requires the reconciliation of state programs to national aims. ${ }^{40}$ Thus, there is a current tendency to view federalism as a

34. See, e.g., England v. Louisiana State Board of Miedical Exam., 263 F2d 661 (5th Cir. 1959).

35. See opinion of Supreme Court in Ferguson v. Skrupa, 31 U.S.L. WeEx 4376, 4377

(U.S. April 22, 1963) ; Williamson v. Lee Optical Co., 348 U.S. 483, 488 (1955).

36. See Kex, Aarerican State Politics: AN Introduction 81-82, 266-67 (1956); Benson, The New Centralization 41-42 (1941); Anderson, Intergovernarewital ReLATTONS IN REVIEW, sipra note 26, at 140-41 (1960).

37. See Key, sipra note 36, at 4, 9; Anderson, The Nation and tue States, Ruvals or Partners? 191-204 (1955); Anderson, Federal and Intergovernarestial Relations 14-15 (1946) ; BENSON, op. cit. supra note 36, at 104-08 (1941).

38. See note 5 supra.

39. See ANDERSON, op. cit. supra note 37.

40. See, e.g., Beloff, National Government and Intentational Govemment, 13 Int' 
process to be comprehended not in terms of relations between the formal institutions of competing or cooperating governments, but in terms of increasing responsiveness to the national interest on the part of local decision makers. There is less need for responsiveness to state and local interests on the part of the federal organs of government, including the judiciary, than there is for responsiveness to the national interest on the part of local legislators. ${ }^{41}$ Though the special tribunal, by its signal for caution, was once thought to demonstrate greater regard for state purposes, ${ }^{42}$ today its utility must be tested by the extent to which it may serve to assist, better than a single judge court, in the process of defending those federal regulatory interests which are bound to conflict with growing bodies of state law.

But since conflicts between legal directives are typically a matter for judicial resolution, the degree to which this responsiveness is to be obtained in the case of federal-state conflicts may well depend upon the inclination of the relevant judges to view favorably, accurately and uniformly the national interest as articulated by Congress or the Constitution. When a suit to enjoin the enforcement of a state statute clearly involves issues of constitutional stature, the relevant judges will be those of a three-judge court. Appropriately for its function, if surprising from the point of view of its creators, the threejudge court appears to be particularly well suited to accomplish a resolution of the conflict most consistent with the aims of modern federal policy.

A comparison between the composition of the three-judge court and the single judge district court suggests that the former is likely to contribute greater sensitivity to the purposes of national programs and the needs of the Constitution. These effects arise from its additive character as well as from the possibilities of geographic dispersion and greater learning which it presents. Thus, each of the three judges brings to the court his experience in applying and interpreting federal law in the context of federal social and economic policies. The doctrinal progeny of Erie $v$. Tompkins further assure that each judge, by participating, albeit indirectly, in the evolution of the state law, will be sensitive to the efforts of state judges. ${ }^{43}$ By its composition the threejudge court provides a forum for the pooling of the national sensitivities of two district judges combined with the broader frame of reference of a circuit judge. Also, court sympathies with the "local" interest, already weakened by the

Org. 538 (1959); Haas, The Challenge of Regionalism, 12 INT'2 Org. 440 (1958); Note, 71 Yale L.J. 344, 354 (1961). Cf. Anderson, The Nation and The States Rivals or PaitTNERS? 211-13 (1955); Holcombe, Thonghts and After-Thoughts on the Future of Democracy in America, Bryce's Amerrcan Commonwentth 113, 130-35 (Howe ed. 1939) ; Anderson, op. cit. supra note 37, at 14-16 (1946) ; LASKr, The Problem of SovereIGNTY 562-63 (1917) ; "Nationalism, then, is Triumphant. The natural question any statute must now raiso is not whether Missouri or Alabama will benefit from its enactment, but whether the United States will so benefit." LASKr, op. cit. supra, at 278.

41. Note, 71 Y ALE L.J. 344, 354 (1961).

42. See text accompanying notes 3,4 supra.

43. See Corbin, The Common Law of the United States, 47 YALE L.J. 1351, 1352 (1938) ; Clark, State Law in the Federal Courts: The Brooding Omnipresence of Eric v. Tompkins, 55 Y ALE L.J. 267 (1946). 
presence of a circuit judge, are presumably dampened further when a district judge is summoned out of his home district to serve on the three-judge bench.

Despite these factors suggesting the special tribunal's greater capabilities from a national point of view, the three-judge court may have a peculiar advantage over the single judge court in its capacity to encourage willing compliance with the decree in the event that injunctive relief is to be granted. The addition of two judges, one of whom is of circuit rank, increases the prestige of the district court and reassures the public as to the breadth and thoroughness of the court's deliberations. Furthermore, public confidence in the impartiality of the tribunal is likely to be enhanced by the presence of one or two judges from outside the forum district. Resentment toward Congress and the federal judiciary is lessened insofar as the frustrated parties feel that their case was given a degree of deliberation and concern commensurate with the drastic nature of the relief granted.

But since it is a reasonable assumption that the courts of appeals are even more nationally oriented and more prestigious than the specially-constituted court required by the three-judge statute, a system of expedited appeals as of right from single judge district courts to the circuit courts in cases now within the scope of section 2281 might be considered a viable alternative to hearings before three judges on the district court level followed by direct appeal to the Supreme Court. Such a scheme would avoid the extremely disruptive withdrawal of an already overworked district judge from his own seat of jurisdiction without assurance that the three-judge tribunal to which he has been summoned, sometimes from a considerable distance, will ultimately be found to have been necessary; $;^{45}$ it would also lessen the appellate burden of the Supreme Court. The single district judge might liberally grant temporary restraining orders or stays of execution in order to stabilize potentially inflammatory situations pending appeal. ${ }^{* 6}$ Although the circuit court would have to make room on its docket for the accelerated appeal, consequent dislocations in

44. In the 1908 Senate debates, Senator Overman commented as follows:

That being so, there being great feeling among the people of the States by reason of the fact that one Federal judge has tied the hands of a sovereign State and enjoined in this manner the great officer who is charged with the enforcement of the laws of the State, causing almost a revolution, as it did in my State, and in order to allay this feeling, if this substitute is adopted and three judges have to pass upon the question of the constitutionality of a State statute and three great judges say that the statute is unconstitutional, the officers of the State will be less inclined to resist the orders and decrees of our Federal courts. The people and the courts of the State are more inclined to abide by the decision of three judges than they would of one subordinate inferior Federal judge...

42 Cong. Rec. 4847.

See Hutcheson, A Case for Three Judges, 47 HARv. L. Rev. 795, 811 (1934).

45. See e.g., Ex parte Bransford, 310 U.S. 354, 361 (1940); Willis v. Walker, 136 F. Supp. 181 (W.D. Ky. 1955) ; Frasier v. Board of Trustees, 134 F. Supp. 589 (AC.D.N.C. 1955) ; Andrew G. Nelson, Inc. v. Jessup, 134 F. Supp. 218 (S.D. Ind. 1955).

46. A district court may grant an injunction pending appeal, under Fed. R. Crv. P. $62(c)$. Rule 62(d) provides for stay upon appeal. 
the overall flow of judicial business would probably result in less inconvenience than is presently generated by the convention of a specially-constituted district court.

Such an alternative, however, contemplating the complete abolition of the section 2281 three-judge court, might resurrect the very same careless attitude toward federal interference with state regulatory establishments which originally engendered the protest leading to its passage. ${ }^{47}$ Further, such a proposal disregards the advisability of employing a more nationally sensitive tribunal to make the lower court determination. ${ }^{48}$ Also, if an initial determination is made by a single judge adversely to the petitioner, the possibility of multijudge determination would rest on the willingness and financial ability of the petitioner to take an appeal to the circuit court, and the results of stch an appeal, if taken, will be strongly influenced by the single judge's findings of fact. The participation of a tribunal of acute national sensitivity should not be subject to such contingencies. Moreover, abolition of the three-judge tribunal overlooks the truly extraordinary nature of the present three-judge mechanism, by which congressional and judicial concern for the gravity of the proceeding is embodied in the presence of two extra judges, giving the parties tangible and impressive assurance that their position will receive special attention. The expectation of a quick appeal, although exceptional, is too abstract to convey such a sense of urgency-to publicize to state citizens and officials the national implications of what they had supposed was local action.

To the extent, however, that the manpower drain imposed by three-judge jurisdiction sufficiently outweighs the advantages achieved through performance of its new function, criticism directed at the continued utility of the statute may be compelling. In fact, the Supreme Court itself has adopted the position that the three-judge tribunal presents serious inefficiencies, ${ }^{49}$ and has enlisted in

47. See text accompanying notes 22-33 supra.

48. Many of the cases dealt with by three-judge courts involve complex factual questions. See, e.g., Wright v. Rockefeller, 211 F. Supp. 460 (S.D.N.Y. 1962); Southern Ry. v. Alabama Pub. Serv. Comm'n, 91 F. Supp. 980 (M.D. Ala. 1950); Missouri-Kansas* Texas R.R. v. Williamson, 36 F. Supp. 607 (W.D. Okla. 1941). The factual determinations would, under the proposed revision, be made by a district court of one judge, and would be binding on the court of appeals. Thus the three-judge capacities for legitimation and nte tional awareness would not be brought to bear on possibly determinative factual findings until too late. Furthermore the three-judge court often is called on to grant or deny interlocutory injunctions in 2281 cases. Under the proposed scheme, the denial of an interlocutory injunction by the single judge would be appealable to the circuit court. In such appeals, a "reasonable discretion" standard is applied to the action of the district judge, in consideration of the latter's on-the-scene appreciation of the facts threatening injury to petitioner. Circuit courts are reluctant to find an abuse of discretion. Thus the three-judge function would not be operative on the district court level, and would be operative on the circuit court level only within narrow limitations. Interlocutory injunctions would be largely beyond the scope of three-judge consideration on their full merits, although the denial of temporary relief might be harmful to that aspect of the national interest invoked by the petitioner, and although the granting of temporary relief might evoke strong local resent* ment. See Henderson v. Burd, 133 F.2d 515 (2d Cir. 1943), 146 A.L.R. 714.

49. Supra note 16 . 
support of its objections a perhaps fictitious congressional concern for judicial efficiency. ${ }^{50}$ But while the Court's concern for the inefficiencies of the threejudge court structure is expressed in terms of the "dislocation of the normal structure and functioning of the lower federal courts," sul such arguments seem most defensible in terms of unmentioned but severe demands upon the time and energies of the Justices themselves, who, by Section 1253, to deny appeals from three-judge courts properly convened under Section 2281. Thus, during the October terms from 1958 through 1961, the Court decided 36 cases on direct appeal from Section 2281 courts, 19 of which received memorandum treatment. These cases constituted $0.48 \%$ of all petitions for review placed before the Court. ${ }^{53}$ Assuming that all the memorandum decisions received only the summary treatment usually given in denying petitions for grant of writ of certiorari, the three-judge court cases given plenary treatment constituted $3.5 \%$ of the Court's plenary decisions. ${ }^{5 *}$ Thus, despite some freedom to avoid decision, the court seems to feel obliged to give plenary treatment to a substantially higher proportion of three-judge appeals than to other forms of petition for review. Consequently, given the overall limitation on the Court's capacity for plenary review,, 55 any increase in the number of appeals from three-judge courts will result in a disproportionate decrease in the Court's ability to grant writs of certiorari and, hence, in its freedom to choose the cases to be heard before it.

One apparent answer to this problem is for the Court to cloak itself with greater discretion by generous use of memorandum decisions and a procrustean application of the "lack of substantial federal question" standard.00 Although

50. Phillips v. United States, supra note 16 at 250; see also Florida Lime \& Avocado Growers, Inc. v. Jacobsen, 91 (Frankfurter, J. dissenting).

51. Florida Lime \& Avocado Growers, Inc. v. Jacobsen, silpra note 50, at 92 (1960) (Frankfurter, J., dissenting).

52. This section provides:

Except as otherwise provided by law, any party may appeal to the Supreme Court from an order granting or denying, after notice and hearing, an interlocutory or permanent injunction in any civil action, suit or proceeding required by any Act of Congress to be heard and determined by a district court of three judges.

28 U.S.C. $\S 1253$ (1958). For a detailed survey of the manner in which $\S 1253$ has been applied in constitutional litigation, see Comment, The Three-Judge District Court and Appellate Review, 49 VA. L. REv. 538 (1963).

53. See tables published in The Supreme Court 1961 Term, 76 HARv. L. REv. 54, 81 (1962); The Supreme Court 1960 Term, 75 HaRv. L. Rev. 40, 85 (1961); The Supreme Court 1959 Term, 74 HaRv. L. Rev. 81, 99 (1960); The Supreme Court 1958 Term, 73 HaRv. L. Rev. 84, 129 (1959).

54. During the four year period, the Court decided 7603 cases. Of the 496 decided by full opinion, 479 were with oral argument. See tables published in HAsv. L. REv, supra note 53. The Court hears oral argument in only a small fraction of the crses given memorandum treatment. Only nine such cases were decided with oral argument during the 1961 term. 76 HARv. L. REv. 54, 81 (1962).

55. See Hart \& Wech sler, The Federal Courts and the Federal Systeur 1394-1404 (1953).

56. Plainly, the criterion of substantiality is neither rigid nor narrow. The play of discretion is inevitable, and wherever discretion is operative in the work of the Court 
such an approach, converting appellate jurisdiction into the equivalent of certiorari jurisdiction, might be workable, a severe modification of the Supreme Court's role seems undesirable. In the first place, so to limit review wotld deny some appellants the one appeal "as of right" to a higher tribunal which adheres to every other litigant in civil cases tried in the federal district courts and which it is intended that they shall have. ${ }^{.7}$ Secondly, the fact that application of the standard must be procrustean may have inadvertent and unfavorable doctrinal results, since dismissal for lack of a substantial federal question, though motivated by considerations of manpower efficiency at the Supreme Court level, carries the implication that the three-judge court was initially improperly con* vened. ${ }^{58}$ Similar objection may be raised, moreover, to those cases which the Court decides on the merits by unexplained memorandum opinions. Unlike the denial of a petition for grant of writ of certiorari, memorandum decisions have effects which, because uncertain, are unfortunate in their failure to give guidance for future action. ${ }^{50}$ And the pressures to decide reveal the third weakness of appeal, as compared with certiorari jurisdiction : the Court lacks

the pressure of its docket is bound to sway its exercise. To the extent that there are reasonable differences of opinion as to the solidity of a question presented for decision or the conclusiveness of prior rulings, the administration of rule 12 [now rules 13 (2) and 15] operates to subject the obligatory jurisdiction of the Court to discretionary considerations not unlike those governing certiorari.

Frankfurter \& Landis, The Business of the Stpreme Court at October Term, 1929, 44 Harv. L. REv. 1, $12-14$ (1930).

Most attorneys are well aware of the fact that the Court may and does exercise its discretion in passing on applications for certiorari but insofar as appeals are concerned they harbor the mistaken impression that review is obligatory and that where they have an appeal "as of right" they are entitled to oral argument on the merits. ... Jurisdictional statements and petitions for certiorari now stand on practically the same footing....

Willey, Jurisdictional Statements on Appeals to U.S. Supreme Court, 31 A.B.A.J. 239 (1945). See Hart, The Time Chart of the Justices, 73 HARv. L. Rev. 84, 88-89 (1959).

57. [I]t has long since become impossible to defend the thesis that all the appeals which the Court dismisses on this ground are without substance. ... Thus, the Court seems to have proceeded upon the view that a "right" of appeal not only does not include a right to be heard orally, but does not include even a right to have the case considered upon plenary briefs. This view is hard enough to accept when it is the appellant who loses. But when the practice works to the prejudice of the appellec through a reversal on the jurisdictional papers, it seems impossible to reconcile with conventional conceptions of due process of law. In such cases the appellee, having had no adcquate notice of the possibility, finds himself finally foreclosed without any real opportunity for argument at all.

Hart, The Time Chart of the Justices, 73 HARv. L. REv. 84, 89 n.13 (1959). The appellant is barred by $\S 1253$, note 52 stpra, from escaping these difficulties through an appeal to at circuit court of appeals.

58. See Note, Supreme Court per curiam Practice: A Critique, 69 Harv. L. Rev. 707, 711-14 (1956). Even where the dismissal for lack of a substantial federal question effectively affirms a judgment for plaintiff the same implication would seem to attach. Cf. Bailey v. Patterson, 369 U.S. 31 (1962) and text at note 11 stipra.

59. Id. at 715-18. 
the freedom it might desire to postpone decision on large and controversial issues to a later day. ${ }^{60}$

To the degree that the Justices' criticism arises from the appellate process prescribed for three-judge courts rather than from the nature of the three-judge device itself, such arguments do not justify curtailment of three-judge functions so much as alteration of the appellate structure. Such modification seems required if further gerrymandering of congressionally defined jurisdictional boundaries by an overburdened Court is to be avoided. The problem must be solved, not by narrowing judicial techniques, but by amendment or repeal of the direct appeal statute. ${ }^{61}$ Since deliberateness and careful consideration, not speed, are thought to be principal virtues of the three-judge court, such lengthening of the appellate process does not seem destructive of the special tribunal's worth, while it enables a more realistic approach to its potentialities and costs at the original jurisdiction level. ${ }^{22}$

It is true that critics, including some Justices, ${ }^{03}$ have charged that judicial disruption at the three-judge level itself constitutes a sufficient dislocation to necessitate the abandonment or severe limitation of the special tribunal as an integrative device in the federal framework. Convention of three-judge courts causes further confusion of already crowded dockets and diverts judicial manpower from the task of clearing those dockets. Such disruptions, moreover, are

60. See Bickei, The Least Dangerous Branch ch. 4 (1962).

61. The idea of a direct appeal from a three-judge tribunal, now embodied in 1253, originated with the Expediting Act of 1903, 32 Stat. 823, which applied to antitrust cases brought by the United States. Its scope has gradually increased as new classes of cases, including those now within 2281, were required to be heard by specially-constituted courts. HART \& WECHSLER, note 55 supra at 47-48. Prior to the 1948 consolidation in 1253 (62 Stat. 926), the various situations in which direct appeal was required were separately codified. See Reviser's Note to 1253 (1958). That there is no necessary connection between three-judge jurisdiction and direct appeal is indicated by the phrase "except as otherwise provided by law" in 1253. Congress has in fact severed the requirement of a specially-constituted district court from direct appeal in cases arising under Chapter XV of the Bankruptcy Act, 56 Stat. 790 (1942). And, in condemnation proceedings under the Tennessee Valley Authority Act, 48 Stat. 70 (1933), 16 U.S.C. \& 831 (1958), appeal from the required three-judge court (three district judges) goes to the court of appeals. Hence, a certain degree of selectivity in connection with the direct appeal requirement would not be unprecedented. And, in fact, the Justice Department has recently asked Congress for legislation substituting review by the courts of appeals for direct appeal in antitrust cases (see Expediting Act of 1903 supra), except where the Attorney General or the trial judge certifies that the case is of special importance. See N.Y. Times, April 29, 1963, p. 28, col. 6. If, in viev of the burden imposed upon the Supreme Court by $\S 1253$, Congress were to permit an aceclerated appeal to the court of appeals from three-judge courts in certain types of cases currently within the direct appeal requirement, with a right to subsequently petition the Supreme Court for writ of certiorari the disadvantages of appeal to the intermediate court from a decision of a single district judge (see note 48 stpra and accompanying text) would not of course be present. Moreover, if a speedy determination by the Supreme Court should appear particularly desirable the Court may under 28 U.S.C. § 2101 (e) (1958) grant certiorari even before the circuit court has delivered judgment.

62. See text accompanying notes $44-48$ supra.

63. See notes 18 and 19 supra and accompanying text. 
heightened where judgments are reversed because of incorrect assignment as between one and three-judge courts, ${ }^{64}$ and where convention of three-judge courts seems futile since the result is referral of disputed questions to state courts for interpretation and decision. ${ }^{65}$

Yet the relative infrequency with which three-judge cases have occurred in the past suggests that these efficiency factors are not sufficient in themselves to be dispositive of the fate of the three-judge courts. From 1952 to 1960, the average number of three-judge courts heard per year was 54.4, distributed widely throughout the 86 federal districts. ${ }^{66}$ Three-judge cases represented $.512 \%$ of all trials commenced in district courts during the nine year span ${ }^{67}$ From this already small proportion and indeterminate number of three-judge proceedings must be subtracted since they arose under statutes other than Section 2281.68 The federal judiciary itself, moreover, has provided tacit recognition that the three-judge court does not constitute a serious drain at the original jurisdiction level. Although the Judicial Conference and the Office of the Administrative Director of the United States Courts have expressed concern over increased district court congestion attributable to bankruptcy, ${ }^{60}$ personal injury, ${ }^{70}$ land compensation, ${ }^{71}$ and antitrust cases, ${ }^{72}$ they have never mentioned multiple-judge panels as sources of congestion. ${ }^{73}$ On the contrary, the Judicial Conference has for a number of years advocated the extension of three-judge jurisdiction to include applications for writs in federal habeas corpus actions brought by persons in custody pursuant to the jutdgment of a state court. ${ }^{74}$ But in more recent years the problem of crowding at the district court level may have become more pressing than the figures mustered above, and the apparent attitude of the Judicial Conference, seem to indicate. In 1962, the number of three-judge cases was twice that of the previous year. ${ }^{75}$ Recent

64. As in cases cited in note 45 stipra.

65. See, e.g., NAACP v. Bennett, 178 F. Supp. 191 (E.D. Ark. 1959) ; cf. England v. Louisiana State Bd. of Medical Exam., 194 F. Supp. 521 (E.D. La. 1961).

66. See 1960 Dir. Admin. Off. U.S. Courts Ann. Rep. (hereinafter cited as Director's Report) 116-17; 1957 Director's Report 91.

67. The average number of trials commenced each year, from 1952 to 1958 , was 10,675 . 1960 Director's Report 103.

68. 28 U.S.C. \& 2282 (1958) ; 32 Stat. 823 (1903), as amended, 15 U.S.C. \& 28 (1958) and 49 U.S.C. \$ 44 (1958); 28 U.S.C. § 2325 (1958). See 6 Moore, Federal Practice II 54.05 (4) (2d ed. 1953).

69. See, e.g., 1960 Director's Report 62; 1959 Director's Report 54.

70. See, e.g., 1960 Director's Report 80-81.

71. See, e.g., 1960 Director's Report 90.

72. See, e.g., 1950 Director's Report 113-14.

73. However, the Judicial Conference of the United States has sought the repeal or modification of the three-judge requirement of the Expediting Act (anti-trust cases), 32 Stat. 823 (1903), as amended 15 U.S.C. 28 (1958), on grounds of judicial inefficiency. Sce 1950 Report of the Judicial Conference 13; Report of Attorney General McGrath, appendix to 1949 Report of the Judicial Conference, at 36; cf. N.Y. Times, April 29, 1963, 1. 28 , col. 6 .

74. See 1959 Report of the Judicial Conference 37, and Report of Attorney General Rogers, appendix to 1959 Report at p. 48.

75. 1962 Director's Preliminary Report II-20. 
trends in constitutional adjudication-the undiminished momentum of the desegregation movement, the opening of the federal courts to reapportionment suits, ${ }^{76}$ and last summer's prayer decision ${ }^{77}$-suggest expanded use of multiple-judge courts under Section 2281.

It is certain that the continued drive to expedite the transaction of judicial business in the federal courts will force legislative focus on the durability of the three-judge provision as it presently stands. But a careful balancing of the utility of three-judge courts in a federal structure against the inefficiencies which admittedly exist must weigh the countervailing considerations not in gross, but in particular classes of litigated issues. Complete abandonment of the tribunal in the context of conflict between federal interests and state regulatory measures will eliminate achievement of the peculiar integrative function that three-judge courts can perform. Recognition of wastefulness in the present structure, based largely on the irrelevance of the original motives for the jurisdictional grant, requires not total abandonment, but a reshaping of the jurisdictional standards to encompass only those situations where the three-judge court may accomplish its most valuable functions. Through such selectivity will come an alleviation of the burden upon the time and energies of the federal judiciary.

Such selectivity is not foreign to the area of three-judge courts. Congress has required three-judge courts in a number of situations: certain actions under the anti-trust statutes ${ }^{78}$ petitions for injunctions to restrain the enforcement of an order of the Interstate Commerce Commission $;^{70}$ cases arising under Chapter XV of the Bankruptcy Act; ${ }^{\mathbf{8 0}}$ and condemnation proceedings under the T.V.A. Act. ${ }^{81}$ In addition, by providing special judicial protection for voting rights in the Civil Rights Act of 1957,82 Congress may be said to have demonstrated that it would have the ability to condition federal threejudge jurisdiction according to the weight it feels necessary for a parlicular class of constitutional rights.

What guidelines, then, may serve to assist the congressional draftsmen in recasting the jurisdictional grant? The present statutory standard, requiring a constitutional challenge of a state statute or administrative order, is now a blunt and indiscriminate tool for performing the task of functional selection. The test of constitutional attack is too broad in the sense that it brings within its sweep cases not needing the special tribunal's peculiar integrative talents; its very breadth has invited the present judicially imposed narrowing, which

76. Sixteen of the post-Baker reapportionment suits compiled in Prof. MfeCloskey's forward to The Supreme Court, 1961 Term, 76 HARv. L. REv. 54, n.14 (1962), and in a Comment, Baker v. Carr and Legislative Apportionments: A Problem of Slandards, 72 YALE L.J. 968 (1963), were heard by three-judge courts.

77. Engel v. Vitale, 370 U.S. 421 (1962).

78. 32 Stat. 823 (1903), as amended, 49 U.S.C. 44 (1958).

79. 28 U.S.C. \$2325 (1958).

80. 56 Stat. 790 (1942).

81. 48 Stat. 70 (1933), as amended, 16 U.S.C. $\$ 83(x)(1958)$.

82. 28 U.S.C. $\S \S 1343,1344$ (1958); 71 Stat. 637,42 U.S.C. $\S 1971$ (1958). 
excludes issues for which the integrative function seems necessary. Three other functional guidelines, however, may be suggested to assist in the specification of issues for three-judge adjudication. First, the effect of the legitimating function, secured by the extraordinary panoply of three-judge convention, ${ }^{80}$ seems desirable where an aroused, resentful reaction is likely to follow the granting of an injunction. A situation requiring legitimation is most likely to exist where the state statute under attack is responsive to widely felt political attitudes; current examples are the racial segregation cases. Similarly, in reapportionment cases, where the federal court is likely to engage in a prolonged, not always harmonious, dialogue with the state legislature, a three-judge coturt would be appropriate because of its greater dignity and ability to elicit a compliant response. ${ }^{84}$ And, arguably, the importance of the legitimating function in pacifying state objections is sufficiently strong to justify invocation of a three-judge court, even when prior Supreme Court decisions have predetermined the outcome of the local controversy. ${ }^{85}$ Second, the more acute national sensitivities of the special tribunal suggest that statutory revision should preserve its function for those cases in which a federal constitutional or statutory provision requires strict uniformity of application throughout the country, for example, the discharge provisions of the Bankruptcy Act. ${ }^{80}$ Finally, the ability of a nationally sensitive tribunal to enforce provisions whose unobstructed application is closely linked to some aspect of the national interest which Congress considers particularly essential suggests that these also be placed under its guardianship, where there is a possibility of conflict with state statutes. The Emergency Price Control Act of $1942,{ }^{87}$ the Smith Act, ${ }^{88}$ and the Civil Rights Act ${ }^{80}$ are examples of such provisions.

On the other hand, those classes of cases which fail to meet the stated criteria can be withdrawn from three-judge jurisdiction. Fourteenth amend-

83. See note 44 supra and accompanying text.

84. See, e.g., Sobel v. Adams, 208 F. Supp. 316 (S.D. Fla. 1962); Toombs v. Fortson, 205 F. Supp. 248 (N.D. Ga. 1962), discussed in 20 Congressional Quarterly Weckly Report 1302, 1305 (1962); Comment, Baker v. Carr and Legislative Apportionments: $A$ Problem of Standards, 72 Y ALE L.J. 968 (1963).

85. See text accompanying notes 11,12 supra. Such a requirement would, of course, be a repudiation of the Bailey approach, $i b i d$.

86. 52 Stat. 851 (1938), as amended, 11 U.S.C. \& 35 (1958); see International Shoe Co. v. Pinkus, 278 U.S. 261 (1929). Part II of Interstate Commerce Act, 54 Stat. 898, 899 (1940), provides another example; United States v. Pennsylvania R.R., 323 U.S. 612 (1945).

87. 56 Stat. 23 (1942).

88. 54 Stat. 670 (1940), as amended, 18 U.S.C. $\$ 2385$ (1958); cf. Pennsylvania v. Nelson, 350 U.S. 497 (1956).

89. 71 Stat. 634 (1957). Hines v. Davidowitz, 312 U.S. 52 (1941), suggests another type of case in which Congress might wish to guard the federal interest by requiring a threejudge court, notwithstanding the additional strain on federal judicial manpower. On appeal from a three-judge district court the Supreme Court held that the Pennsylvania Alien Registration Act was invalid, on (supremacy clause) grounds of preemption by the federal Alien Registration Act. The Court stated :

Our system of government is such that the interest of the cities, counties and states, no less than the interest of the people of the whole naiion, imperatively requires that 
ment attacks on state economic regulatory measures, for example, or similar attacks on exercises of state police power for the public health and safety might well be excluded from the jurisdictional grant, since they do not at present fit the three integrative standards of legitimation, uniformity and essentiality. In the absence of extraordinary cause for congressional concern over a continuing danger of confiscatory or discriminatory action, the national interest is not sufficiently threatened by state unresponsiveness or unrest to justify the additional strain on judicial manpower. In addition, new jurisdictional standards ought not to require three-judge hearing of supremacy clause cases, apparently included within the present grant, ${ }^{90}$ unless the integrative function is served in a particular type of conflict. Such cases, capable of decision and public acceptance within the traditional structure of the federal court system, should revert to adjudication by single-judge tribunals.

federal power in the field affecting foreign relations be left entirely free from local interference.

Id. at 63. And if the Court's present or future use of the "no substantial federal question" rationale could be found to create a pattern of abstention in particular categories of cases, these categories might provide useful standards for excision or inclusion.

90. See Kesler v. Department of Pub. Safety, 369 U.S. 153 (1962). There the Court held that cases in which the supremacy clause provides the only constitutional ground for attack upon a state statute raised constitutional questions within the meaning of $\$ 2281$. Although in Kesler, the conflict between the Utah Safety Responsibility Act and the discharge provision of the Bankruptcy Act would seem to require three-judge adjudication because of the importance of uniform application of the federal statute (see note 84 supro), the integrative guidelines suggested in the text accompanying notes 83-89 supra clearly do not require that supremacy clause cases, as a class, be heard by threc-judge courts. 